Article

\title{
Evidence of Coastal Changes in the West Coast of Naxos Island, Cyclades, Greece
}

\author{
Niki Evelpidou*D, Alexandros Petropoulos $(\mathbb{D}$, Anna Karkani $\mathbb{D}$ and Giannis Saitis \\ Faculty of Geology and Geoenvironment, National and Kapodistrian University of Athens, Panepistimiopolis, \\ 15784 Athens, Greece; alexpetrop@geol.uoa.gr (A.P.); ekarkani@geol.uoa.gr (A.K.); saitij@geol.uoa.gr (G.S.) \\ * Correspondence: evelpidou@geol.uoa.gr; Tel.: +30-2107274297
}

Citation: Evelpidou, N.; Petropoulos, A.; Karkani, A.; Saitis, G. Evidence of Coastal Changes in the West Coast of Naxos Island, Cyclades, Greece. J. Mar. Sci. Eng. 2021, 9, 1427. https:// doi.org/10.3390/jmse9121427

Academic Editor: Alfredo

L. Aretxabaleta

Received: 2 November 2021

Accepted: 11 December 2021

Published: 14 December 2021

Publisher's Note: MDPI stays neutral with regard to jurisdictional claims in published maps and institutional affiliations.

Copyright: (c) 2021 by the authors. Licensee MDPI, Basel, Switzerland. This article is an open access article distributed under the terms and conditions of the Creative Commons Attribution (CC BY) license (https:// creativecommons.org/licenses/by/ $4.0 /)$.

\begin{abstract}
Coastal lagoons and dunes are of great ecological importance, not only for providing habitats for rare flora and fauna, but also for protecting coastal areas from rising sea levels and storms, etc. Even though these features are unique for sustainable development and are extremely important to the natural environment and economy, they are one of the most vulnerable and threatened ecosystems due to their small size. The western coasts of Naxos (central Aegean Sea) represent an example of such phenomena, with various wetlands bordered by low-lying sand dunes. The aim of our study is to assess the vulnerability and pressures of the western coasts of Naxos Isl. by taking into consideration both natural and anthropogenic factors. We used a variety of approaches for the environmental and geomorphological study of the coastal zone to achieve this goal, including: (a) study of aerial photography from 1960 until today, (b) systematic seasonal aerial monitoring by drone, since 2015, (c) use of DGPS for the mapping of the coastal zone and for obtaining detailed topographic sections, and (d) dune mapping. Our findings reveal the vulnerability of the western coasts of Naxos due to sea level rise, tectonic subsidence, and a variety of anthropogenic pressures, such as uncontrolled parking, vegetation uprooting, sand extractions, and heavy touristic traffic. Therefore, the protection of the sand dunes, their restoration where they have been eroded, the definition of a zone of control, and restriction of human activities must be a key priority.
\end{abstract}

Keywords: dunes; coastal lagoons; coastal hazards; sea level rise; climate change; anthropogenic pressure

\section{Introduction}

In recent decades, the coastal zone has been continuously sustaining increased tourist activities, but it is also directly impacted by climate-change factors (i.e., continuous sealevel rise, increased frequency and magnitude of storms) as well as non-climate change related factors (i.e., land use, population increase, water management, subsidence) [1] Climate change, particularly associated with the ongoing sea-level rise, is intensifying coastal erosion and inundation, resulting in significant environmental changes, habitat loss (directly or indirectly), as well as significant financial loss through its effects on local populations and tourism in the area. The consequences of natural phenomena, such as tsunamis, hurricanes, and storm surges, are greatly magnified due to increasing population densities at the coast. On the other hand, increasing human pressure in the coastal zone is reducing natural buffer zones and causing the so called "coastal squeeze" where valuable habitats, coastal processes, coastal ecosystem services, etc. are all squeezed into narrow zones. The observed climate change and the resultant sea level rise, the increase of storm surges and other extreme events that afflict the coastal zone and, also, the rapidly increasing population of the coastal zone will surely have a significant impact not only on the resilience of the coastal systems, but also on the strategies of adaptive services and goods [2-4].

In the case of the Mediterranean region, approximately $70 \%$ of the countries' population lives in the coastal areas [5]. The Mediterranean coastal zone hosts a notable number of visitors, with increasing demand for access to infrastructure and accommodation. This 
concentrated urbanization in combination with industrial development has led to significant pressures on the coastal environment, including habitat loss, degradation and fragmentation and hence loss of biodiversity. In the absence of proper management, these pressures threaten the values that have led to such visitation numbers and development.

Sandy coastal ecosystems, lying in the transition zone between marine and sedimentary terrestrial environments, are subject to continuous changes in their morphology and vegetation $[6,7]$, while showing great biodiversity, in terms of plant species and communities [8]. These fragile ecosystems hosting beaches, wetlands, and dune habitats are threatened by coastal erosion and human impact [9]. Coastal dunes constitute an unstable, but dynamic geomorphological unit of the coastal zone. Sand dune systems hold the dynamic role in the coastal zone, as they constitute a natural barrier protecting the inland from eroding wave action, while they also act as water filters, enhancing the quality of coastal water. Sand dune habitats provide niches for plants and animals, with many rare and often endangered species. Nowadays, the loss and degradation of the coastal dunes is mainly owed to human activities [10], which typically differentiate the natural processes on the coastal zone and therefore modify the system dynamics. These activities may be categorized into six sectors [10,11]: (a) housing and recreation, (b) industrial and commercial use, (c) waste disposal, (d) agriculture, (e) mining, and (f) military activities.

At the same time, coastal wetlands are very important and valued features due to their high biodiversity and ecosystem services, such as preventing floods, cleansing waters, and recharging groundwater aquifers. Wetlands also host a wide variety of flora and fauna, providing habitat for rare and endangered species. Many of the Mediterranean coastal wetlands are threatened by a number of factors, such as modifications of their natural functions, over-fishing and hunting, excessive pumping, and partial drainage [12]. Hence, these coastal environments are particularly vulnerable and worthy of attention and protection for their specific ecosystem functions.

In this context, our study aims to assess the vulnerability and pressures on the western coasts of Naxos, considering both natural and anthropogenic factors. This is achieved through a series of methodologies that include (a) the study of aerial photographs from 1960 until today, (b) systematic seasonal aerial monitoring by drone since 2015, (c) coastal zone mapping and topographic sections through the use of DGPS, and (d) mapping of coastal dunes.

\section{Study Area}

Naxos Island is located in the central part of the Aegean Sea, $200 \mathrm{~km}$ SE from Athens (Figure 1). The island has a mountainous relief, and the midland is dominated by a mountain chain from the north to the south across the island. The western part of Naxos is characterized by low relief, with sandy beaches along an extensive coastal zone and, consistently, concentrates the majority of the communities in the vicinity of our study area. Typically, the western coasts are composed of a sandy beach, bordered by low lying sand dunes, lagoons and an alluvial plain. Dune-fields are well-developed along the western coast, with an almost continuous extent from Chora (Naxos city) to Pyrgaki, $20 \mathrm{~km}$ further south. These dunes were already mapped both during the realization of the geological map of Naxos [13] and in recent research focusing on coastal evolution [14]. According to past field investigations [15], six main dune fields are found (Figure 1), commonly separated transversal by granodiorite promontories, jutting out at the coastal area. 


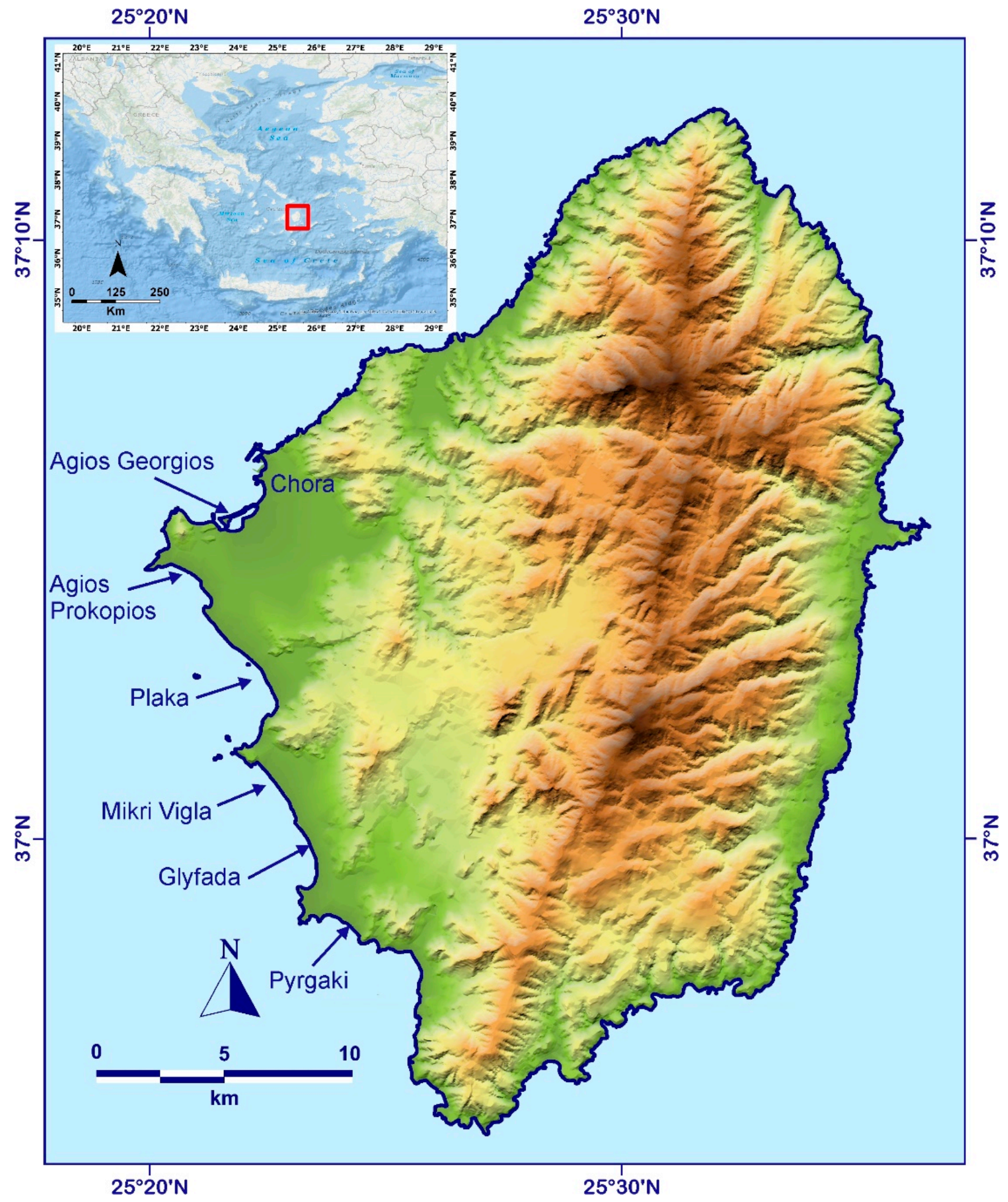

Figure 1. Location of the study area and the main localities discussed in the text. 
The wind, which plays a key role in the formation and evolution of the dune fields, is characterized by a predominance $(>60 \%)$ of northerly winds (Etesian Meltemi) [16]. The southerly winds represent about $25 \%$, while the westerly and easterly winds occur only occasionally. The trend is similar when considering the storm winds ( $>7$ on Beaufort scale). According to 10 years of data (1995-2004), on an annual basis, the most common propagating ripples originate from the $0^{\circ}$ and $225^{\circ}$ areas, with an incidence of $38 \%$ and $25 \%$ respectively (Figure 2a). The average value of the significant wave height is $0.73 \mathrm{~m}$, with typical values between $0-0.5 \mathrm{~m}$, while the maximum value of the significant wave height is $5.6 \mathrm{~m}$ with direction N-NW (area $352^{\circ}$ ) (Figure 2b). The highest significant wave heights originate from the $\mathrm{N}$ and SW directions (area 345-10 and 225 $5^{\circ}$ [17]. With respect to fetch length, it extends to $40 \mathrm{~km}$ for the northern direction, (extending up to Mykonos Island), $55 \mathrm{~km}$ for the southeastern direction (extending up to Sikinos and Folegandros islands), and to $30 \mathrm{~km}$ for the southern direction, limited by Ios island.

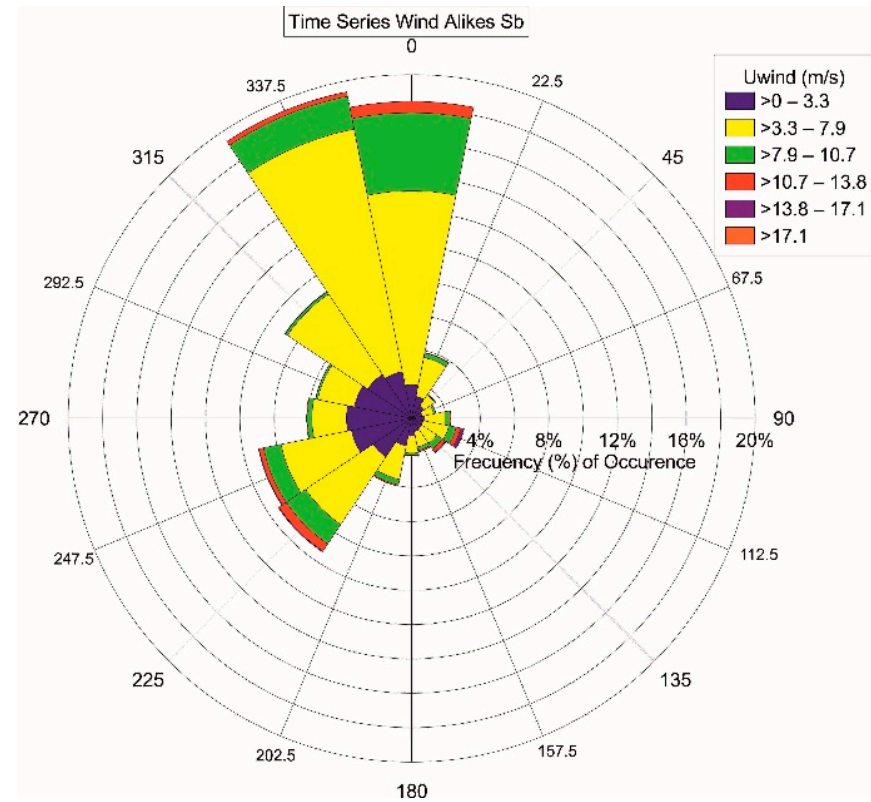

(a)

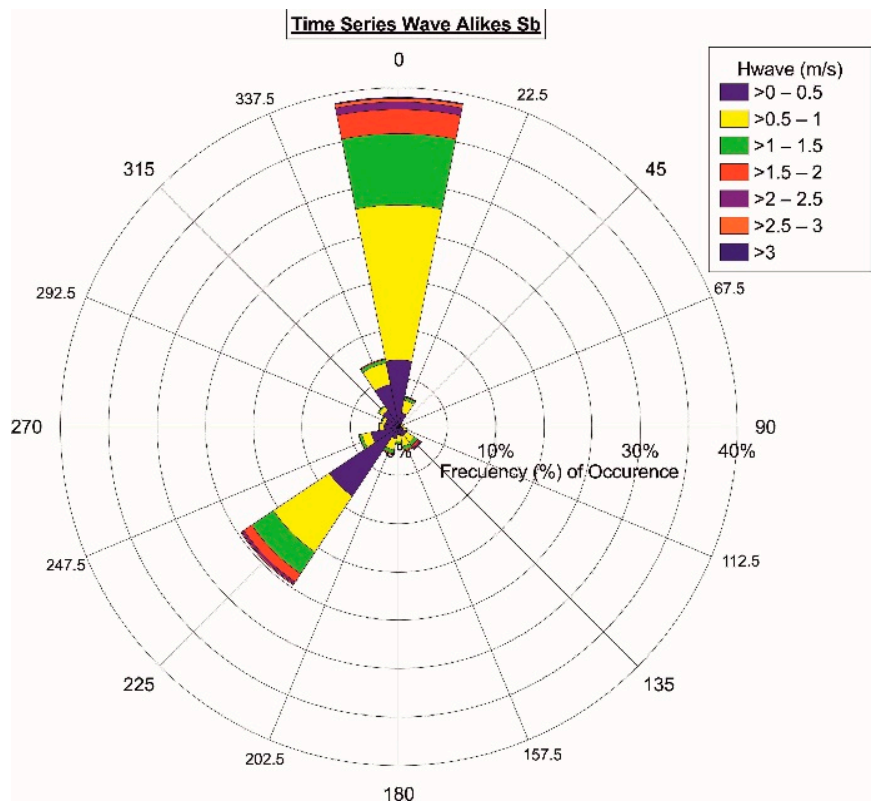

(b)

Figure 2. (a) Wind and (b) wave rose diagrams for the study area.

Late Holocene Evolution of the Western Coasts of Naxos

On the western coasts of Naxos, several landforms testify to the late Holocene evolution of the area and the relative sea level changes. A series of slabs of submerged beachrocks have been identified at five different sites at western Naxos, reaching depths of $-6.3 \mathrm{~m}$, providing evidence on the morphological configuration of the coastline and the coastal evolution in the last few millennia [18].

At Agios Georgios, three boreholes have been accomplished, providing insights into the paleogeography of the bay for the last 6000 years [19]. Around 6000 BP, the bay of St. Georgios was protected by an elongated beachrocks reef, which extends almost parallel to the modern coastline. For the period between 6144 BP until 232 BP, St. Georgios was an active lagoon. Sedimentological and palaeontological data have shown that the embayment was changing from a coastal environment to an environment frequently alternating from shallow marine with freshwater input to a brackish mesohaline one [20]. Parts of the beachrocks reef, during that period were periodically submerged and sea water would enter into the bay [19].

A few kilometers to the south, the Mikri Vigla area was also protected by a beachrock bench. Analysis of sediments and micro-faunal content from three boreholes revealed that between $3800 \pm 50 \mathrm{BP}$ to $1625 \pm 45 \mathrm{BP}$, the site was an active lagoon [19]. The deepest 
beachrock partially protected the lagoon 2000 years ago, while the shallower beachrock was partially protecting the area up to $1000 \mathrm{AD}$ [21]. At least during the Bronze Age (3300-1200 BC), the site of Vigla may have been used as a place where boats could anchor, even though bound for other destinations [19].

Fossil palaeoshorelines in the form of tidal notches have been identified at Naxos island, as well as other Cycladic islands. At least seven former shorelines were found at depths between $280 \pm 20$ and $30 \pm 5 \mathrm{~cm}$ below the present sea-level [22]. The vertical sequence of several submerged notches indicates rapid subsidence events, probably of seismic origin that have taken place after $3300 \mathrm{BP}$, suggesting a subsidence rate of about $0.8-0.9 \mathrm{~mm}$ per year [22].

The presence of the submerged beachrocks $[18,23]$, the coastal corings from western Naxos $[19,20]$ along with the multiple submerged notches testify to relative sea level rise during the late Holocene. Similar analysis from the neighboring island of Paros [24] and comparisons with sea-level predictions from two GIA models suggest an average rate of tectonic subsidence $\sim 1.0 \pm 0.4 \mathrm{~mm} / \mathrm{yr}$ since $5500 \mathrm{cal} \mathrm{BP}$ [24]. This subsidence trend in the central Cyclades is most likely owed to gradual long-term subsidence [24-26] in combination with seismic events [22], due to the dominance of an extensional structural pattern [27].

\section{Methodology}

For this work, we used a series of methodologies for the environmental and geomorphological study of the western coastal zone and the shallow submarine area of Naxos, which included: (a) photointerpretation of aerial photographs from 1960 until today. The aerial photographs from 1960 and 1988 were obtained from the Hellenic Military Geographical Service, were photointerpreted through stereoscopic observation and were used for the documentation of coastal features; (b) systematic seasonal aerial monitoring by drone, since 2015, (c) mapping of the coastal zone and topographic sections using DGPS (Differential Global Positioning System). Specifically, a DGPS-GNSS Spectra SP60 was used for this purpose, which offers an accuracy of $5 \mathrm{~cm}$; (d) dune mapping, which was also accomplished using DGPS.

Dune-fields are well-developed along Naxos western coast, with an almost continuous extent from Chora (Naxos city) to Pyrgaki, $20 \mathrm{~km}$ further south. These dunes were already mapped both during the realization of the geological map of Naxos [13], the geomorphological map [28] and in recent research focusing on the coastal evolution [19,28]. In this study, we performed detailed topographic mapping of the coastal dunes, using a DGPSGNSS Spectra SP60 with accuracy of $5 \mathrm{~cm}$. We performed cross sections on the dune-fields defining the back-shore boundary, the boundaries of the sand dunes, the vegetation cover, the coastline, and the corresponding sea level. The cross sections were performed on the dune-fields of Agios Prokopios, Plaka, Mikri Vigla, Glyfada, and Pyrgaki (Figure 3). The sand dunes are named according to their proximity to the coastline. Thus, the closest to the coastline series of dune fields were coded as $\mathrm{T} 1$ and the more remote are coded ascendingly (T2, T3, etc.). 


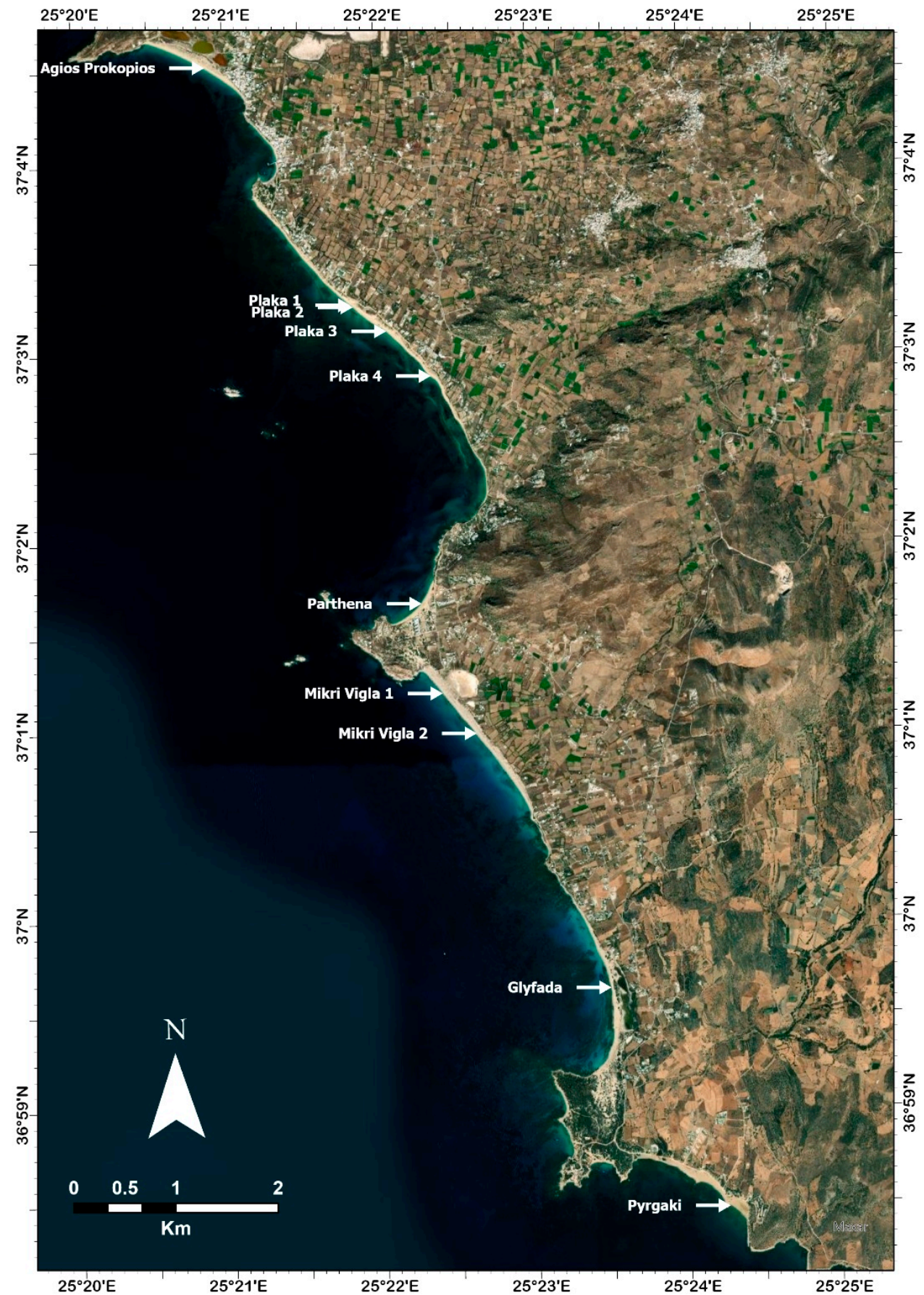

Figure 3. Locations of the investigated dunes fields and the cross sections.

\section{Results}

\subsection{Agios Georgios Tombolo}

The development of Agios Georgios tombolo was studied using aerial photographs from 1960 until today. From the study of the aerial photographs of 1960, 1988 and 2015 the tombolo shape has changed. In 1960 the small island of Manto was connected to the rocky islet on the west. Beachrocks are also present on the north shore of Manto. In 1960 the islet's distance from the shore was $22.90 \mathrm{~m}$ and covered an area of $\sim 3230.2 \mathrm{~m}^{2}$. During 1988, its morphology has changed and the distance from the shore was decreased to $16.60 \mathrm{~m}$ and its covering area was reduced to $\sim 3000.6 \mathrm{~m}^{2}$ (Figure 4a). Additionally, it can be observed that a narrow land that was once connecting Manto and the rocky islet was submerged. During fieldwork in 1997-2000 [28], the rocky islet was still submerged along with three 
beachrock slabs. Today, the tombolo is formed between the Manto islet and the main coast of the island and it is even possible to have access by foot (Figure 4b). The area of Manto has been reduced between 1960 and 1988 by 53.47\% [28]. Nowadays, the area reaches $25,861.7 \mathrm{~m}^{2}$.

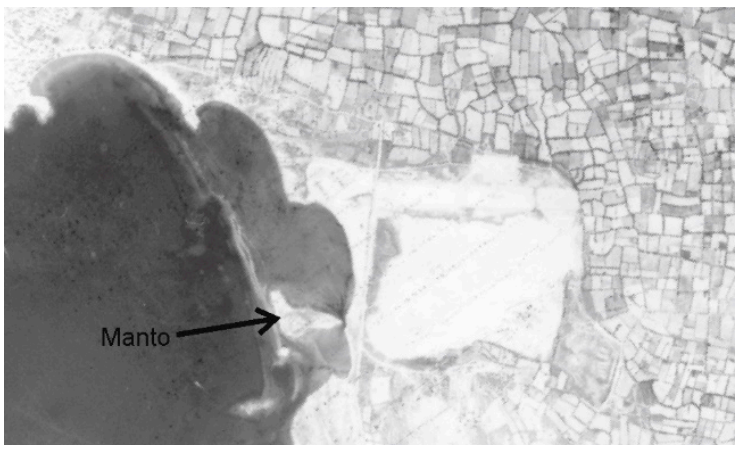

(a)

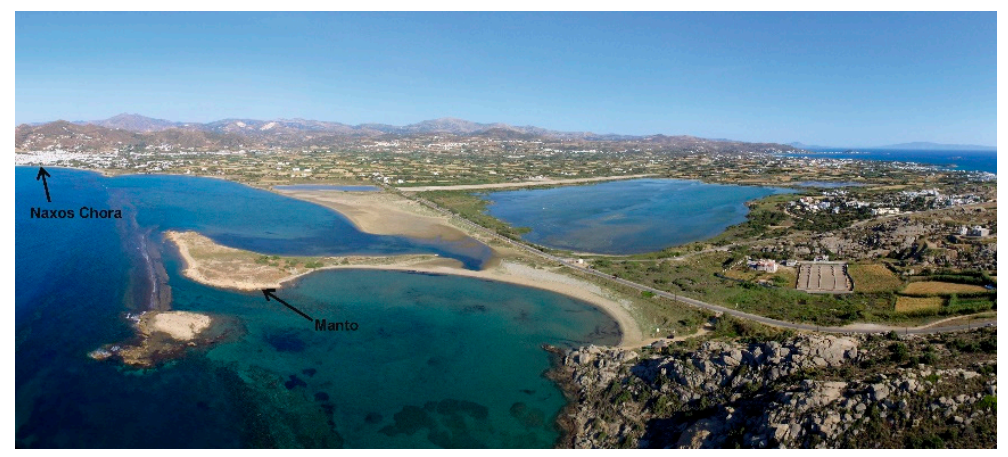

(b)

Figure 4. (a) Aerial photograph of 1988; (b) Drone image from 2019 of the present-day tombolo.

Human driven changes in the area are also noted in the aerial photograph of 1988. A coastal road has been built near the shore as well as and the construction of Naxos airport. Today, many human activities affect the area, however they seem to have no impact on the tombolo.

\subsection{Agios Prokopios}

The coastal zone of Agios Prokopios has a length of $1100 \mathrm{~m}$ and a width ranging between $15 \mathrm{~m}$ and $124 \mathrm{~m}$, while the coast has a gentle dip of $8^{\circ}$. The coastal area is characterized by the presence of sand dunes and a lagoon. The dunes are extensive and cover an area equal to $2 / 3$ of the beach. This area, during the summer months, is used as a parking space. Behind the dunes there is a lagoonal system, parallel to the coastline (Figure 5a). During summer, when the water table is lower, the lagoon dries up and it is separated into three lagoons. The presence of sand dunes also functions as a natural barrier to the water communication of the three seasonal lagoons with the sea. The coastal zone of Agios Prokopios is partially delimited by the arbitrary and irregular road network that has been developed on the dunes, which limits the width of the land beach to $15 \mathrm{~m}$ and by a sequence of low dunes with vegetation.

The dune ridge is located only in the northern half of Agios Prokopios beach, in contrast to the southern part, which is replaced by dense urbanization. The presence of anthropogenic pressure at the specific area is strong despite the attempts of preservation, which seem insufficient. The composition of the sand dunes is characterized as sand, which is provided by the eroded local granodiorite.

The performed cross section is located almost at the middle of the three-lagoon system (Figure 5b). The T1 dune has a width of $40 \mathrm{~m}$ with a maximum elevation of $2.48 \mathrm{~m}$. This dune is characterized by vegetation on its landward part which is protected by the sea and sea spray. The T2 dune has a width of $43 \mathrm{~m}$ with a maximum elevation of $2.3 \mathrm{~m}$ while it is fully covered by vegetation. Between the T2 and T1 dune, there is a manmade unconformity serving as a road for light weight vehicles. At the back border of the T2, there is a coastal road which separates the dune field. The last T3 dune has width of $20 \mathrm{~m}$ and elevation of $0.55 \mathrm{~m}$. The three-lagoon system is located behind the dunes with a width of $102 \mathrm{~m}$ and the deepest part reaches $9 \mathrm{~cm}$ below sea level, which is located $240 \mathrm{~m}$ from the shoreline and $12 \mathrm{~m}$ from the back border of the lagoon. 


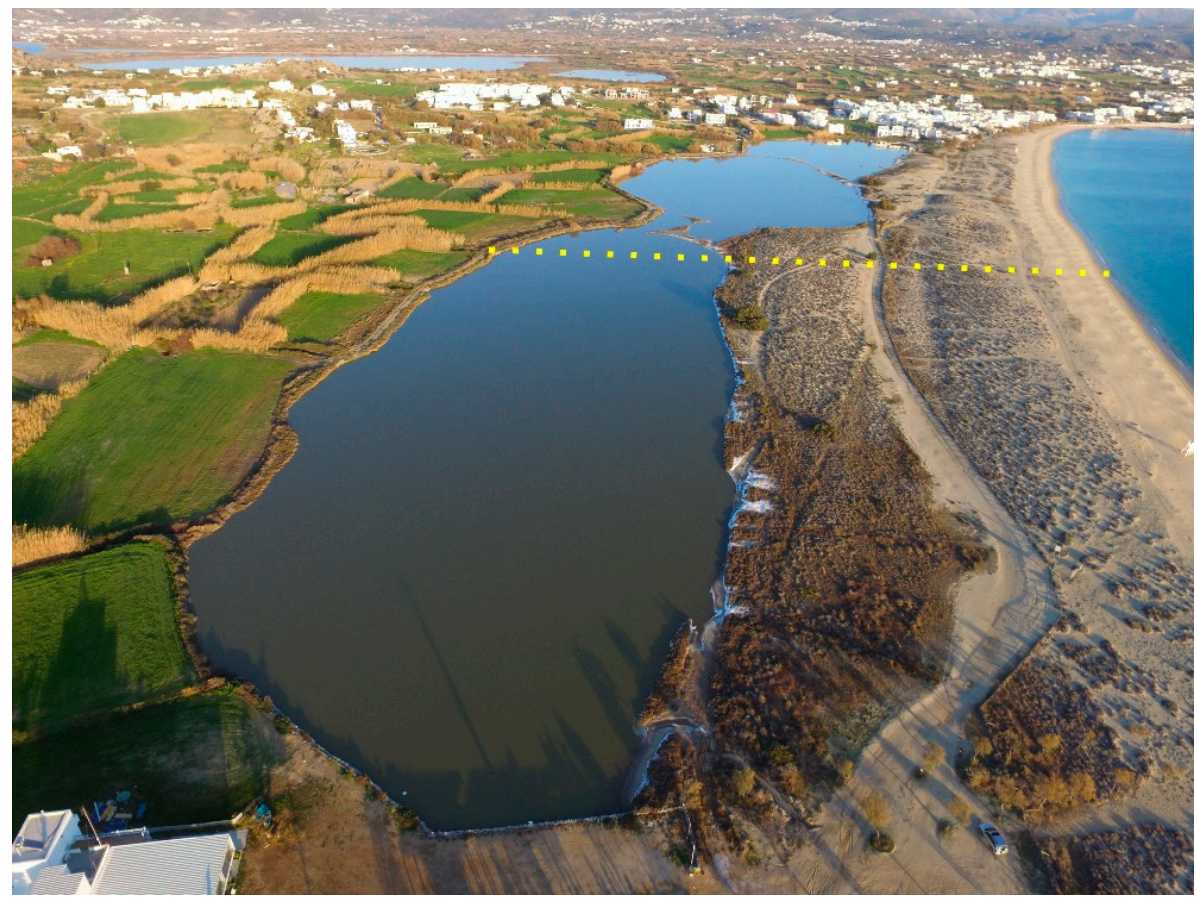

(a)

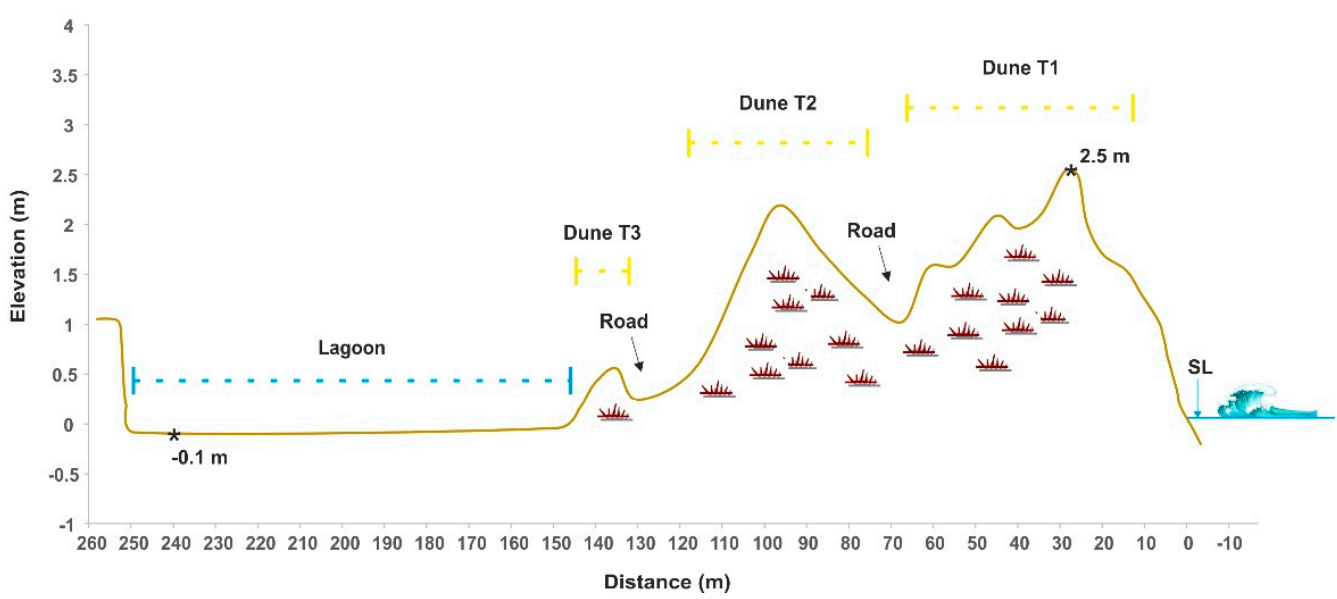

(b)

Figure 5. (a) Aerial photograph of Agios Prokopios dunes and lagoonal system, with the location of the cross section; (b) Cross section of Agios Prokopios site.

\subsection{Plaka}

The coastal zone of Plaka area is characterized by well-developed dunes and seasonal streams appear at the southern part (Figure 6a-c). The shape of the sand dune systems is rectilinear and changes to an arc shape on the southern part, characterized by complexity and two series (T1, T2). Their length is located for about $3 \mathrm{~km}$ with a width of $15 \mathrm{~m}$. The presence of beachrocks in front of the beach leads to the deposition of the finest parts of sediments, as the beachrocks prevent the transport of coarser sediments by the wave. Therefore, the wind transports the finer grains more easily and forms, in a shorter time, higher sand dunes without vegetation. The fine-grain material of which the sand dunes are composed leads to the erosion of their lower layers. It is noted that the area of Plaka shows absence of any lagoonal features. 


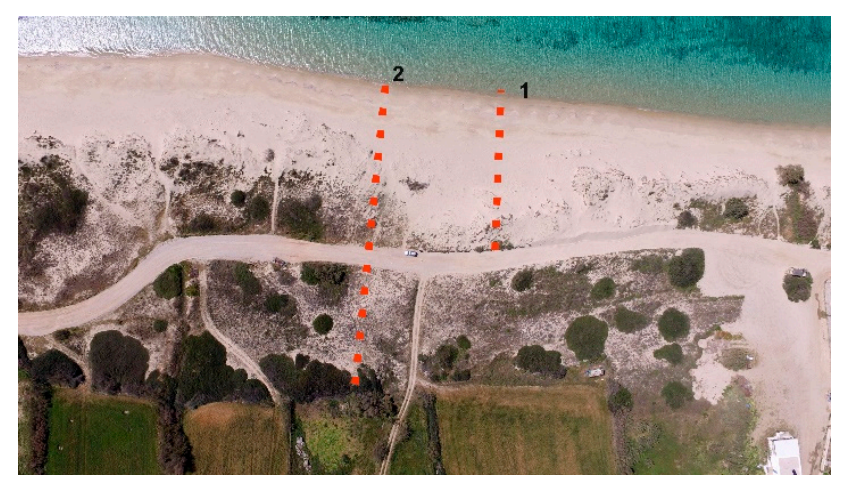

(a)

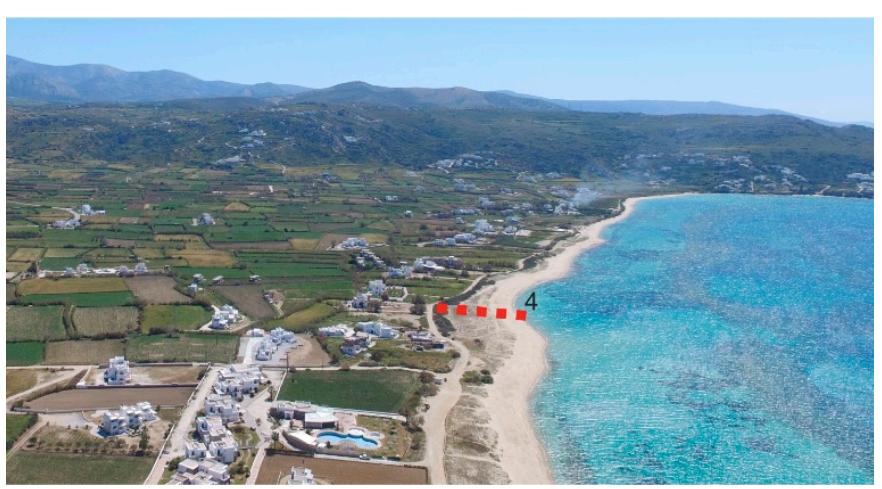

(c)

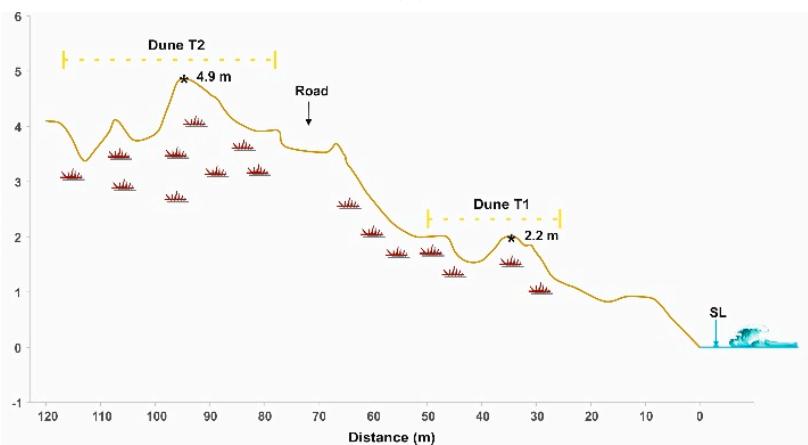

(e)

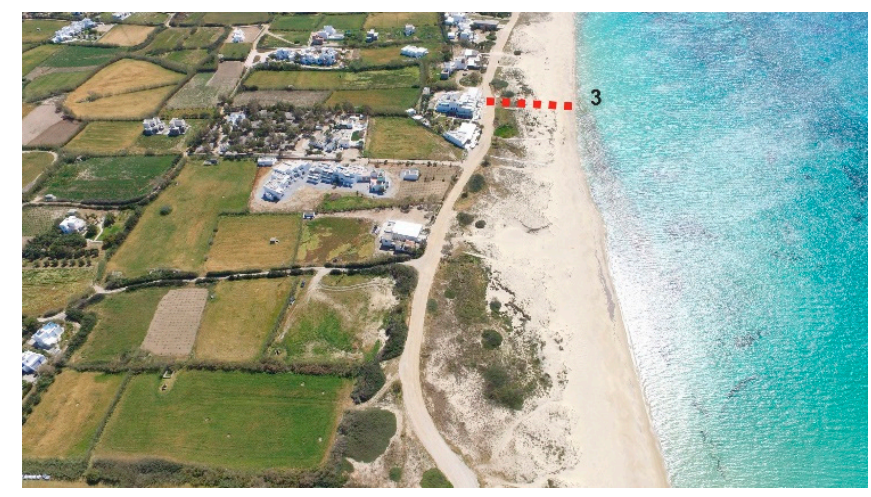

(b)

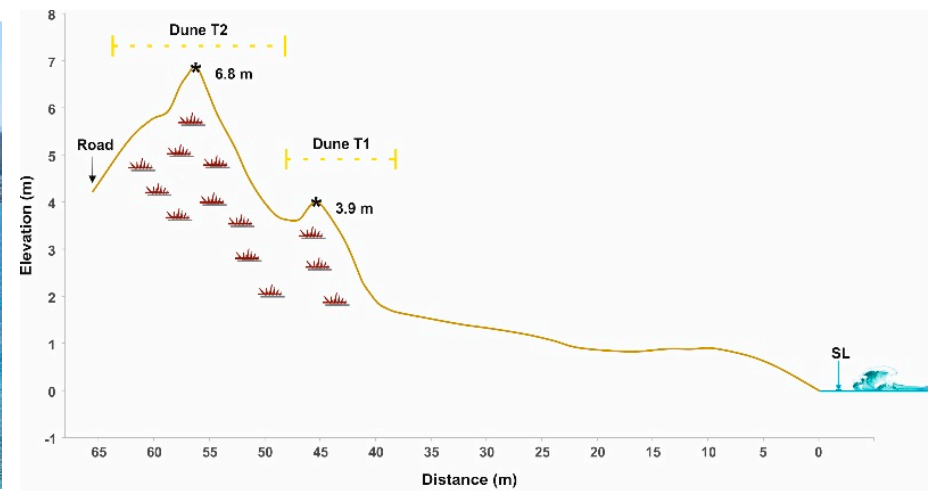

(d)

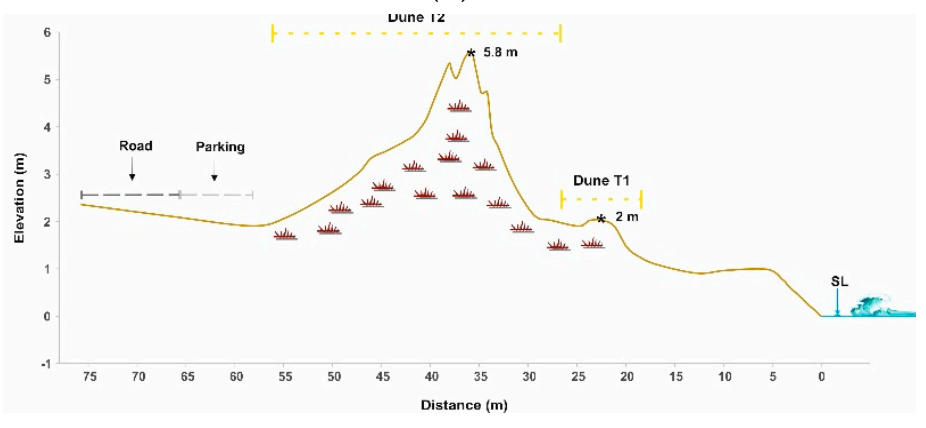

(f)

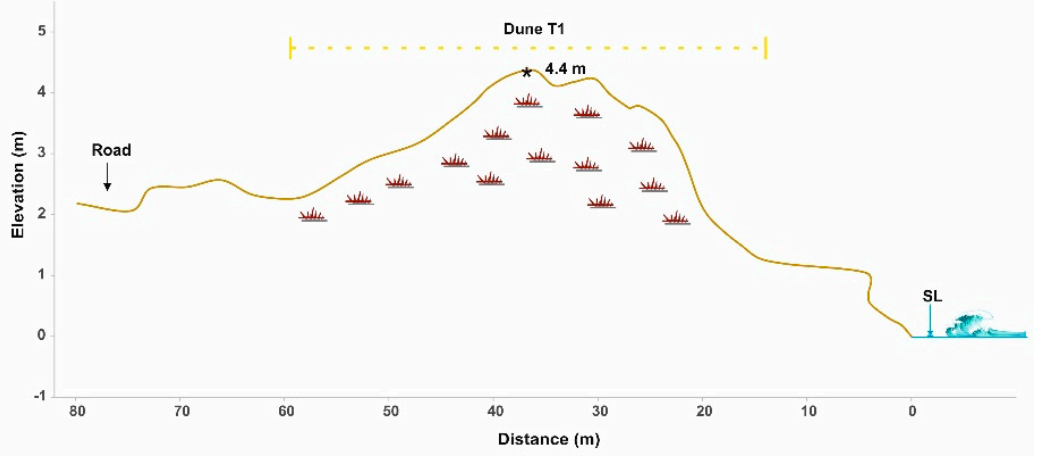

(g)

Figure 6. Aerial photographs of Plaka site, with the locations of (a) cross Sections 1 and 2; (b) cross Section 3 and (c) cross Section 4; (d) Sketches of cross section Plaka 1; (e) Plaka 2; (f) Plaka 3 and (g) Plaka 4. 
Due to the extended Plaka dune-fields and their morphological variety, we created four cross sections: Plaka 1 (Figure 6a,d), Plaka 2 (Figure 6a,e), Plaka 3 (Figure 6b,f), and Plaka 4 (Figure 6c,g).

On the cross section, Plaka 1 is located at the north part of Plaka beach. The T1 dune has a width of $9 \mathrm{~m}$ with a maximum elevation of $3.9 \mathrm{~m}$. Following the T2 dune has a width of $15 \mathrm{~m}$ with a maximum elevation of $6.8 \mathrm{~m}$. Both dune series are stabilized by vegetation. The human impact is observable on the shore as there are organized public sun loungers. Furthermore, a coastal road is cutting through the T2 dune, which is possibly to be extended even further to its landward part.

The cross section Plaka 2, is southern to Plaka 1 in a distance of $45 \mathrm{~m}$. This cross section reveals the complexity of the dune formation as the two series are not easily distinguished. It is believed that human impact may have done alternations on the dune morphology. The dune has a width of $24 \mathrm{~m}$ forming two ridges with a maximum elevation of $2.2 \mathrm{~m}$ above sea level and fully covered by vegetation. The dune is cut off by the aforementioned coastal road and continues with the T2 which has a width of $32 \mathrm{~m}$ forming multi-ridges with the highest one at $4.9 \mathrm{~m}$. The T2 dune is fully covered by vegetation. At the back boundary of T2 dune, many human alternations can be observed as ongoing contractions.

The Plaka 3 cross section is located southern to Plaka 2 at a distance of $400 \mathrm{~m}$. Dune $\mathrm{T} 1 \mathrm{has}$ a width of $7 \mathrm{~m}$ and a maxim elevation $2 \mathrm{~m}$, while T2 has a width of $30 \mathrm{~m}$ with the highest elevation at $5.8 \mathrm{~m}$. A parking and the coastal road are noted in the landward part of T2. Furthermore, intense human activity is present, such as houses, stores and hotels.

Finally, Plaka 4 cross section is located $1 \mathrm{~km}$ southern to Plaka 3. On this cross section, only a T1 dune can be observed with width of $48 \mathrm{~m}$. The dune is fully covered by vegetation and its back boarders the coastal road.

\subsection{Mikri Vigla}

The coast of Mikri Vigla has a total area of $2 \mathrm{~km}^{2}$ and features two natural coastal lagoons clustered on a $0.2 \mathrm{~km}$ stretch of the coast, extensive transitional sand dune systems and a temporary pond formed between the lagoons (Figure 7a). Also, the planting of trees by humans in the sand dunes reflects the desire to protect the dunes or houses near the dunes, especially at the eastern part of the study area, where human constructions were built directly on the dunes. The dunes' shape is semicircular, with a total length of $678 \mathrm{~m}$ and a width $20 \mathrm{~m}$.

Three cross sections were performed at Mikri Vigla area (Figure $7 \mathrm{~b}-\mathrm{d}$ ). The first cross section, Mikri Vigla 1 (Figure 7b), was accomplished on Parthena beach, north of Mikri Vigla village. This cross section indicates two series (T1/T2) of dunes. The T1 dune has a width of $6 \mathrm{~m}$ and a maximum elevation at $3.7 \mathrm{~m}$. T2 dune follows with a width of $24 \mathrm{~m}$ forming two ridges with maximum elevation at $6.8 \mathrm{~m}$. Both dune series are covered by vegetation.

At Mikri Vigla beach, the characteristic cross section, Mikri Vigla 2 (Figure 7c), indicates the two-series dune system protecting the lagoonal system. T1 dune has a width of $55 \mathrm{~m}$ with a maximum elevation at $2.7 \mathrm{~m}$. T2 dune has a width of $25 \mathrm{~m}$ but with a maximum elevation at $0.88 \mathrm{~m}$. Both dunes are fully covered by vegetation. The lagoon extends behind $\mathrm{T} 2$ dune for $170 \mathrm{~m}$ and has the same elevation as the sea level.

The third cross section, Mikri Vigla 3 (Figure 7d), is located $500 \mathrm{~m}$ south of Mikri Vigla 2. At this cross section, three series of dunes are noted. T1 is characterized by a width of $10 \mathrm{~m}$ and maximum elevation at $2.6 \mathrm{~m}$, while $\mathrm{T} 2$, in close proximity to $\mathrm{T} 1$, has a width of $6 \mathrm{~m}$ and $1.9 \mathrm{~m}$ elevation. At the landward part of T2, a coastal road can be observed. The T3 dune has a width of $10 \mathrm{~m}$ and an elevation at $3.4 \mathrm{~m}$. All dunes are covered by vegetation. 


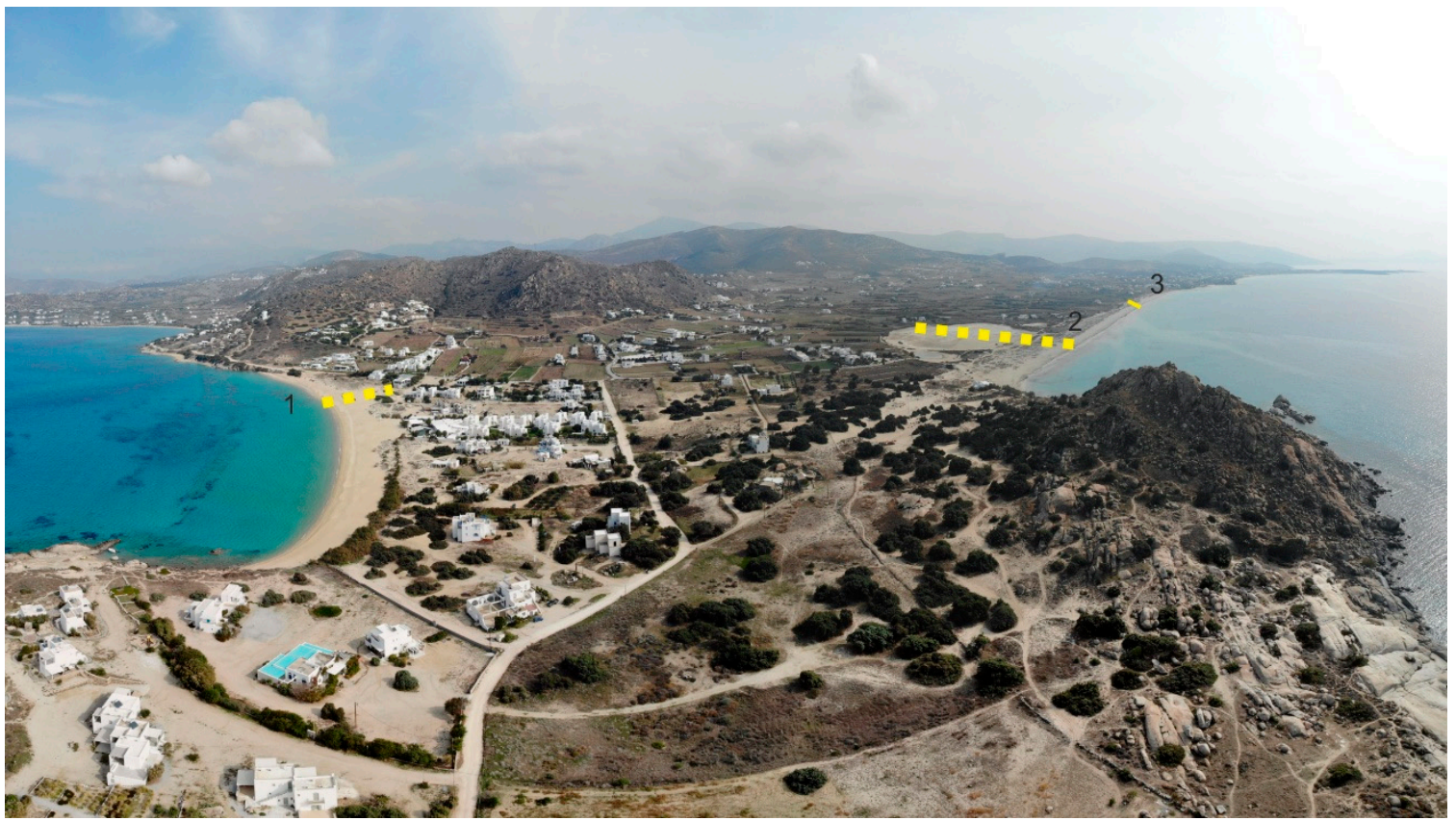

(a)

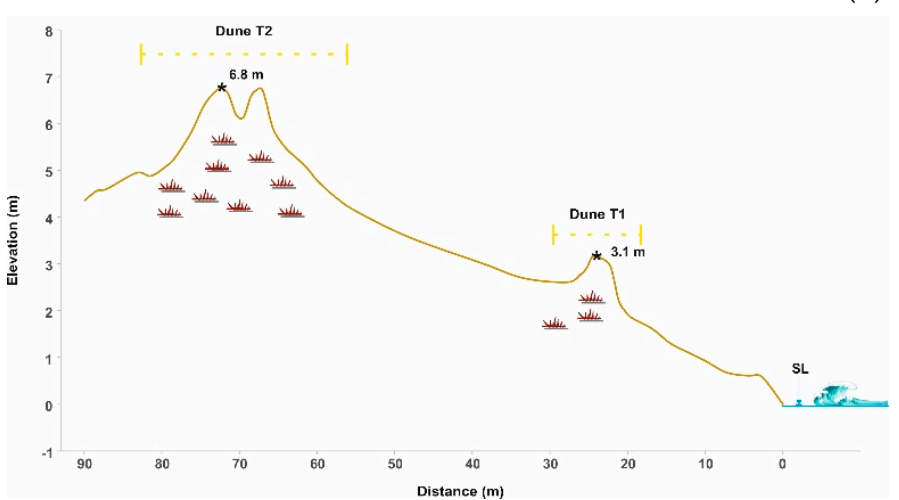

(b)

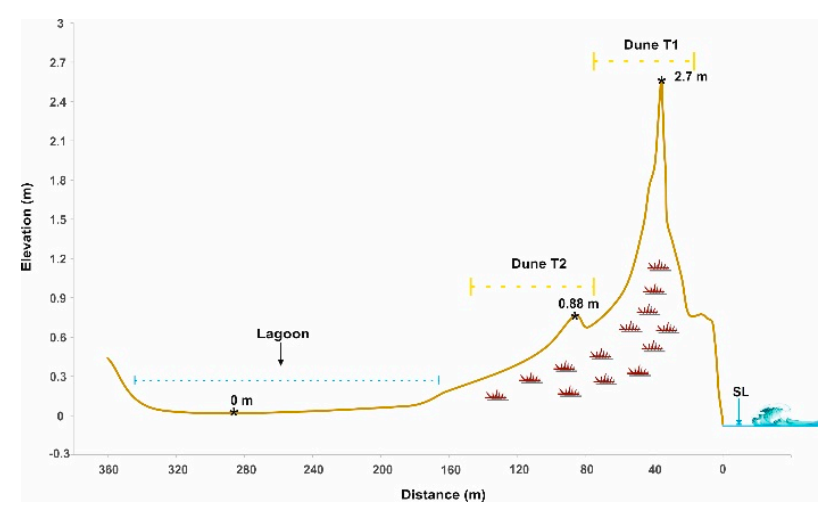

(c)

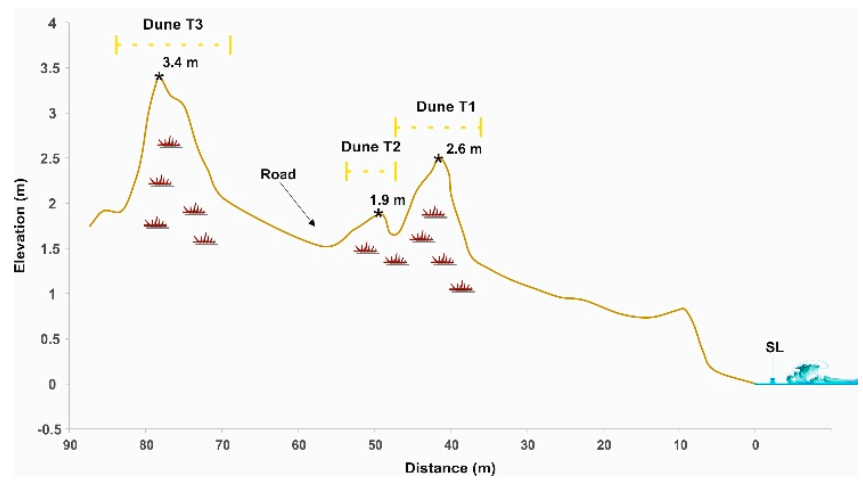

(d)

Figure 7. (a) Aerial photograph of Mikri Vigla site, with the locations of the three sections; Sketch of cross section Mikri Vigla 1 (b); (c) Mikri Vigla 2 and (d) Mikri Vigla 3.

\subsection{Glyfada}

The coastal area of Glyfada is characterized by extensive sand dunes, a seasonal lagoon while and the beach slope is about $12^{\circ}$ (Figure 8a). The total area covered by dunes is $370 \mathrm{~m} 2$ and features two natural coastal lagoons clustered on a $0.13 \mathrm{~km}$ stretch east of Glyfada beach. There is a communication channel at the southern part of the lagoon where 
the dune-fields end. The lagoons are isolated from the sea by extensive sand dune systems, at a distance of about $9.40 \mathrm{~m}$ from the coastline. Their shape is defined as a circular arc with a total length of $2 \mathrm{~km}$ and width of $20 \mathrm{~m}$ until the beach.

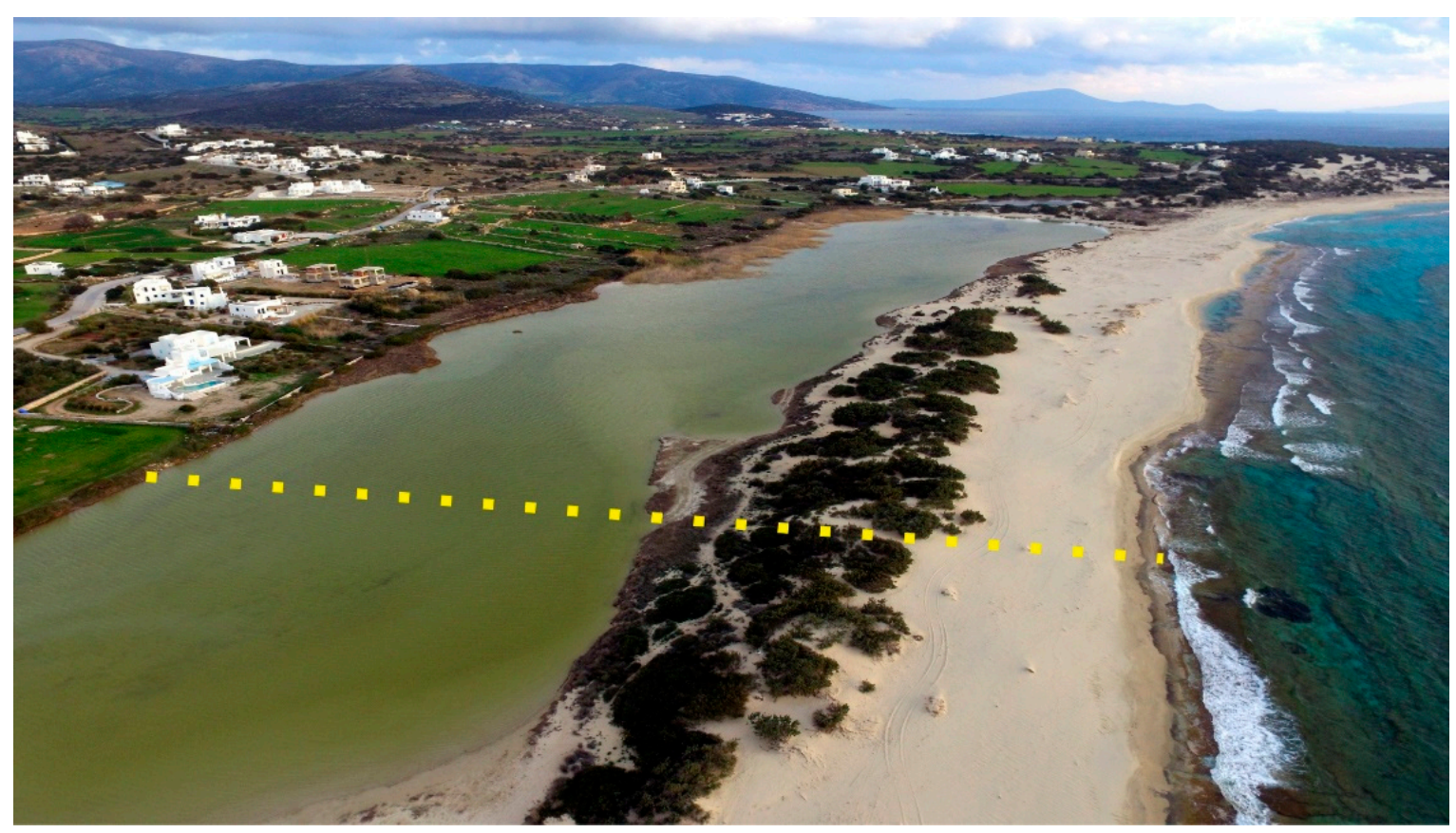

(a)

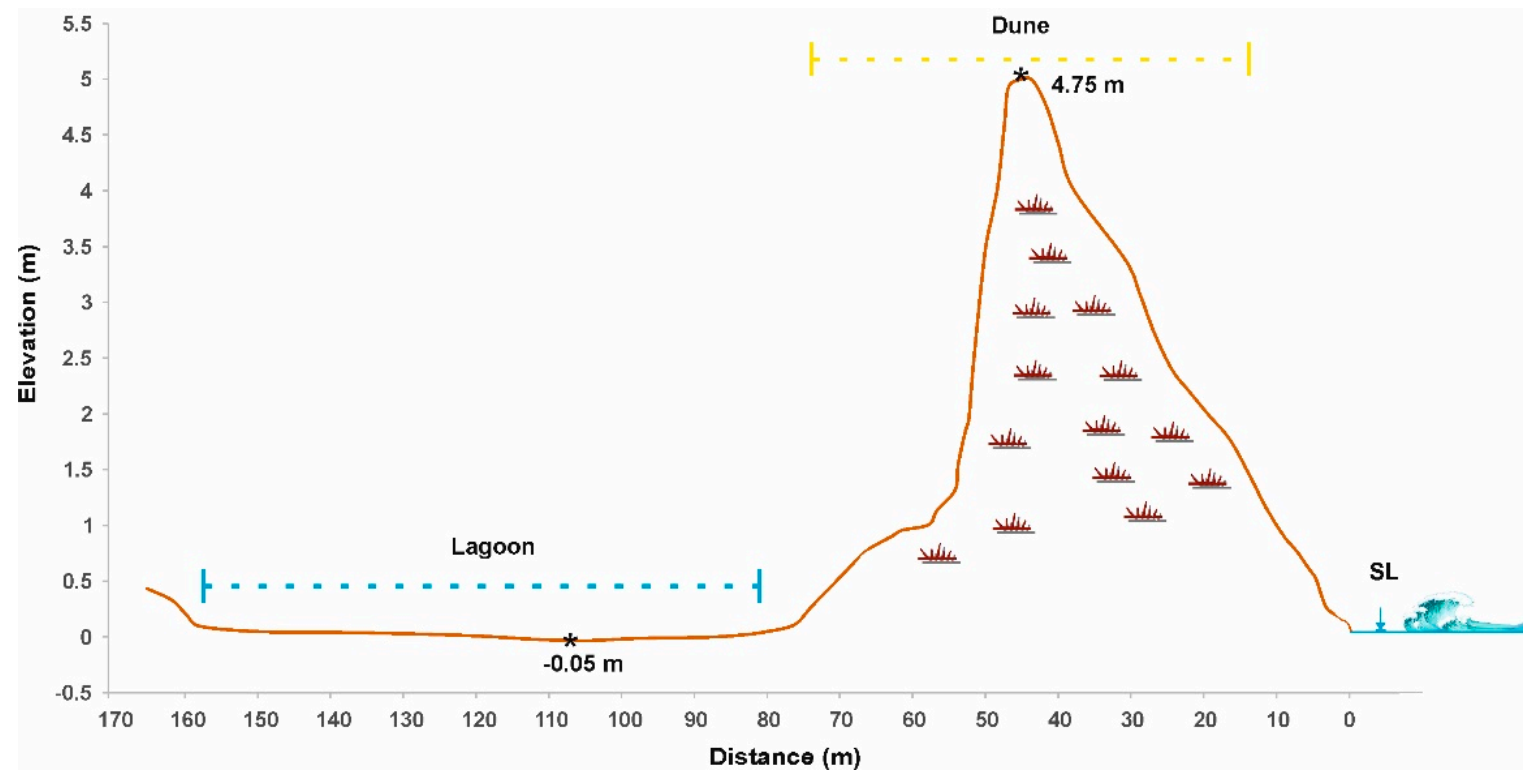

(b)

Figure 8. (a) Aerial photograph of Glyfada site, with the location of the section; (b) Sketch of the cross section.

The typical geomorphological features of Glyfada coastal area are interpreted on a cross section (Figure $8 \mathrm{~b}$ ). The Glyfada dune has $62 \mathrm{~m}$ width forming multiple ridges of $4.75 \mathrm{~m}$ maximum elevation. Behind the dune, the lagoon extends for $77 \mathrm{~m}$ with an elevation of $5 \mathrm{~cm}$ below sea level.

\subsection{Pyrgaki}

The site of Pyrgaki has a total area of $0.12 \mathrm{~km}^{2}$ and the sediment composition of the beach consists of sand mixed with pebbles (Figure 9a). The presence of pebbles can be 
explained by the presence of an old stream, which seems to be no longer active. It is noted that the dunes cover them.

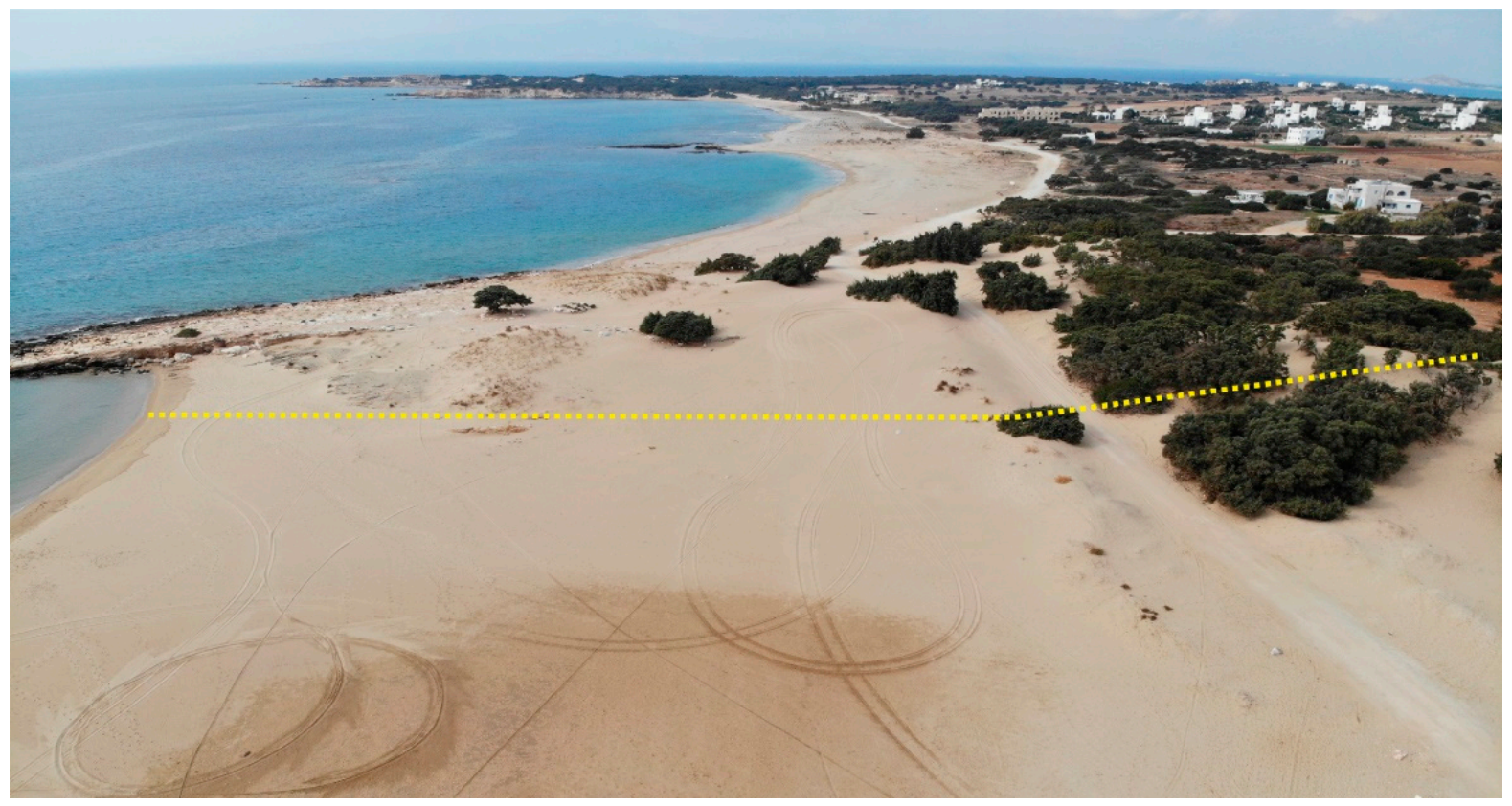

(a)

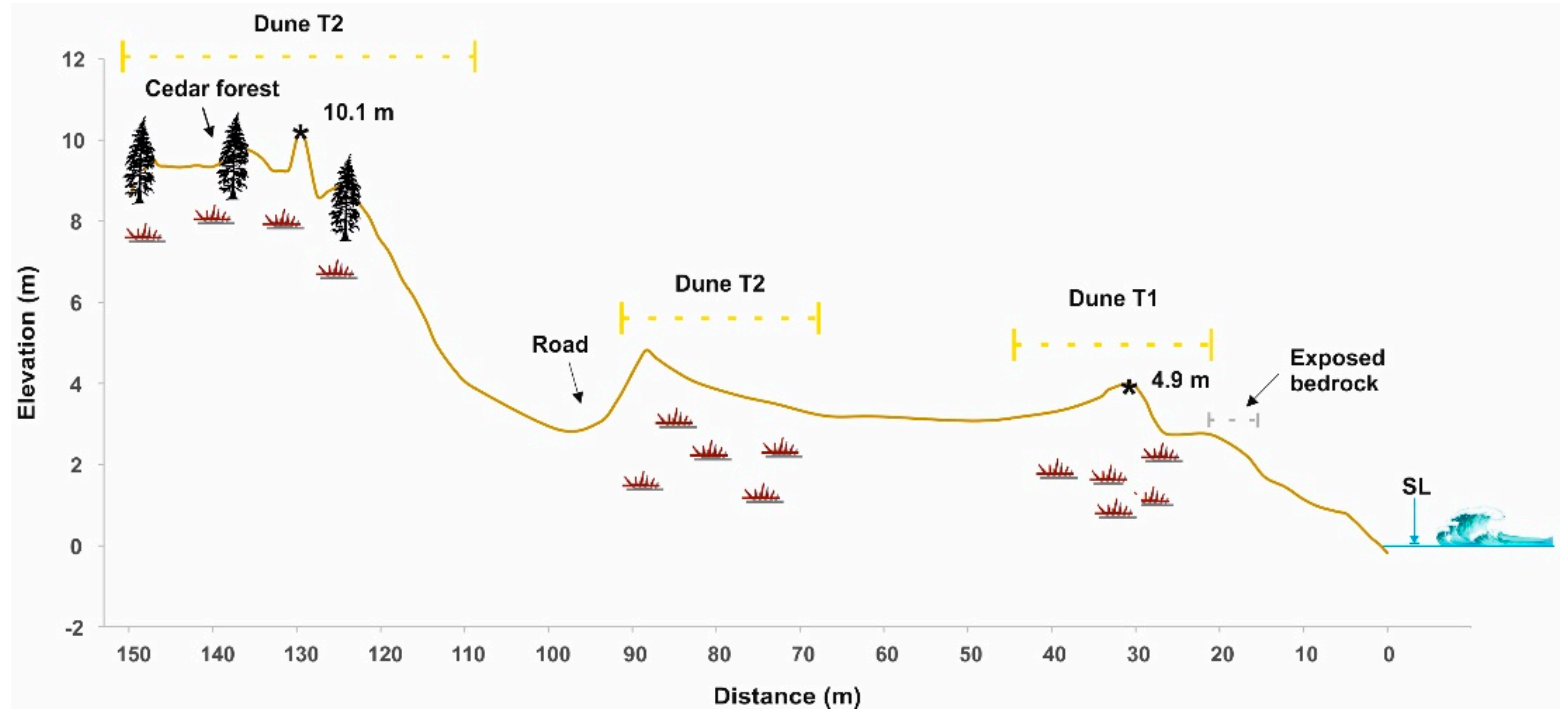

(b)

Figure 9. (a) Aerial photograph of Pyrgaki site, with the location of the section; Parts of granodiorite that have not been eroded protrude to the sea; (b) Sketch of the cross section.

The Pyrgaki cross section indicates an extended two series dune field (Figure 9b). The T1 dune has $20 \mathrm{~m}$ width and an elevation of $4.9 \mathrm{~m}$. The T2 dune has a width of more than $80 \mathrm{~m}$ and a maximum elevation of $10.1 \mathrm{~m}$. This dune is disturbed by a road. All dunes are covered by vegetation while the T2 is fully covered by a cinder field, which creates a unique scenery.

\section{Discussion}

A number of coastal and marine landforms testify to the late Holocene and present-day evolution of the area and the relative sea level changes, providing evidence concerning the morphological configuration of the coastline and the coastal evolution. The coastal zone of 
the western coasts of Naxos is typically composed of a sandy beach, bordered by low lying sand dunes, lagoons and an alluvial plain, while the submarine area is characterized by the presence of a series of beachrock slabs [18-20,28] (Table 1). From North to South, dune fields are developed, at an almost continuous area of $20 \mathrm{~km}$ at the sites of Agios Prokopios, Plaka, Mikri Vigla, Kastraki, Glyfada, and Pyrgaki, defining the back-shore boundary, relative to the coastline. At the same time, natural coastal wetlands (lagoons) extend behind the dunes, inland, below sea level. Sand dunes are one of the most vulnerable and threatened ecosystems of the island. The sand dunes have average dimensions 3-10 m in height and 30-150 $\mathrm{m}$ in width, showing high slopes on the windward and mainly on the leeward side, while the maximum value of the significant coastal wave height is $5.6 \mathrm{~m}$ with $\mathrm{N}-\mathrm{NW}$ direction. Based on the distribution of the dune fields, it seems that the relief, the morphological characteristics of the area, along with the sand source supply have played the major role on their location. On the other hand, the influence of the wind can be recognized in the constant NNW-SSE to N-S orientation of the dune fields. The natural coastal lagoon system extends behind the sand dunes, for 77-170 $\mathrm{m}$, with the deepest part reaching $9 \mathrm{~cm}$ below sea level.

Table 1. The main characteristics of dunes and lagoons of the studied sites.

\begin{tabular}{|c|c|c|c|c|c|}
\hline $\begin{array}{c}\text { Cross } \\
\text { Sections/Dune } \\
\text { Series }\end{array}$ & $\begin{array}{c}\text { T1 (Width, } \\
\text { m-Elevation, m) }\end{array}$ & $\begin{array}{c}\text { T2 (Width, } \\
\text { m-Elevation, m) }\end{array}$ & $\begin{array}{c}\text { T3 (Width, } \\
\text { m-Elevation, m) }\end{array}$ & Lagoon & $\begin{array}{c}\text { Lagoon Elevation } \\
\text { in Relation to Sea } \\
\text { Level (cm) }\end{array}$ \\
\hline Agios Prokopios & $40-2.48$ & $43-2.3$ & $20-0.55$ & $\begin{array}{c}\text { Three lagoon } \\
\text { system-102 m } \\
\text { width }\end{array}$ & -9 \\
\hline Plaka 1 & $9-3.9$ & $15-6.8$ & & & \\
\hline Plaka 2 & $24-2.2$ & $32-4.9$ & & & \\
\hline Plaka 3 & $7-2$ & $30-5.8$ & & & \\
\hline Plaka 4 & 48 & & & & \\
\hline $\begin{array}{c}\text { Mikri Vigla } 1 \\
\text { (Parthena beach) }\end{array}$ & $6-3.7$ & $24-6.8$ & & & \\
\hline Mikri Vigla 2 & $55-2.7$ & $25-0.88$ & & $\begin{array}{c}\text { Two lagoon } \\
\text { system-170 m } \\
\text { width }\end{array}$ & 0 \\
\hline Mikri Vigla 3 & $10-2.6$ & $6-1.9$ & $10-3.4$ & & \\
\hline Glyfada & $62-4.75$ & & & $\begin{array}{l}\text { One lagoon-77 m } \\
\text { width }\end{array}$ & -5 \\
\hline Pyrgaki & $20-4.9$ & 80-10.1 & & & \\
\hline
\end{tabular}

These systems are becoming increasingly vulnerable, due to sea level rise, considering both natural (waves/storms/extreme weather events) and anthropogenic pressures, leads to their erosion and degradation. Anthropogenic pressures include uncontrolled parking, vegetation uprooting, heavy touristic traffic, etc. The study of past aerial photographs reveals that the main pressures on the coastal zone derive from the recent human interventions and the development of touristic and residential constructions. Specifically, at Agios Prokopios area, the development of sand dunes has been affected by human activity, mainly at the southern part of the coast as they have been replaced by dense urbanization, exposing the area to extreme natural phenomena. At Plaka and Pyrgaki, anthropogenic pressures located at the back of sand dunes (e.g., parking area, coastal roads) reduce their width and make them prone to erosion, in combination also with the reduction of clastic feeding from the seasonal streams, making these conditions irreversible. Mikri Vigla is an example of what happens when human removes and degrades sand dunes, as after human constructions built directly on sand dunes, they were forced to take protection measures by planting trees in the sand dunes, reflecting the desire to protect the dunes and constructions near the dunes, especially from the southeastern natural events. The lagoon of Agios Georgios and the seasonal lagoons of Glyfada, Mikri Vigla and Agios Prokopios 
are characterized as significant habitat areas both in terms of biodiversity and population as well as scientific importance. Human intervention in these areas (construction of an airport and creation of cultural fields at Agios Georgios, and a parking area and touristic activities at Glyfada, Mikri Vigla, and Agios Prokopios) led to their degradation, causing significant problems in the biodiversity of the areas and consequently the environment.

The location and morphology of the dune systems make them important variables in the coastal zone and specifically in the advance of seawater in a possible sea level rise, because of global climate change. Sand dunes act as a natural barrier that protects the inland from strong natural phenomena, preventing the penetration of water bodies. In case of sea level rise only by $0.5 \mathrm{~m}$, according to the conservative scenario of the IPCC (2007, 2013, and 2019) [29-31] for the next 100 years, it is estimated that the land to be covered by the sea will be limited in area, due to the high altitudes and slopes of the sand dunes, which contribute to the area as a measure to prevent coastal flooding [32]. Moreover, sand dunes act as filters for water, enhancing and maintaining coastal water quality, while provide niches for highly specialized plants and animals, including numerous rare species and some endangered species. At the same time, coastal wetlands are very important and valued features due to their high biodiversity and ecosystem services.

The combined tectonic subsidence in the study area (submerged beachrocks/notches) along with the ongoing global climate change particularly associated with the sea-level rise, poses a threat to a variety of coastal landforms as well as on several touristic activities that are hosted on the western coasts of Naxos. In the absence of sand dunes, marine flooding will follow not only to the beach, but also to the lagoons and many acres of rural and residential land, resulting in significant environmental changes and financial loss through its effects on local populations and tourism in the area. In addition, sand dunes can also protect from coastal hazards, such as tsunamis, as they can partially absorb tsunami wave energy [33], and in fact the dunes fields of Glyfada offer better protection in comparison to those of Agios Prokopios, as the former have been less impacted by anthropogenic pressures [33].

However, sand dunes of the specific areas are subject to significant environmental pressures, direct and indirect, mainly from human activity, exposing significant parts of coastal areas to the risk of flooding by sea water. In particular, the effects of uncontrolled tourism development (e.g., irregular road network and passages on the sand dunes, sand extractions and clearings), in combination with the reduced supply of material for the development of the sand dunes, results in their leveling and consequently in their destruction. Long-term loss of sand from the beach system will lead to coastal retreat, with the outgoing amount of sand being greater than the incoming. At the same time, the presence of the underwater beachrocks along the shallow submarine area of the western coasts, which extend from many kilometers parallel to the present-day coastline, act as natural breakwaters, protecting the coastal zone from erosion [34]. Their presence and preservation are essential for the protection of the coastal zone. The potential loss of sand dunes is a threat to the wider areas, especially the low-lying coastal areas, from marine floods, resulting in the social, cultural, and economic degradation of the areas.

\section{Conclusions}

The coastal areas of western Naxos are characterized by several landforms such as wetlands that border with low-lying sand dunes. The coastal zone is typically composed of a sandy beach, bordered by low lying sand dunes, lagoons, and an alluvial plain. These systems are increasingly vulnerable due to sea level rises, considering both natural (waves/storms/extreme weather events) and anthropogenic pressures, which lead to their erosion and degradation. The main pressures on the western coasts of Naxos are directly related to the effects of uncontrolled tourism development (e.g., irregular road network and passages on the sand dunes, sand extractions, and clearings). The coastal wetlands of the study area are also burdened with human interventions, impacting their biodiversity. Regarding the sand dunes, these pressures in combination with the reduced supply of 
material, results in their leveling and consequently in their destruction. Therefore, the protection of sand dunes, their restoration where they have been eroded, and the definition of a zone of control and restriction of human activities must be a key priority. The existence of sand dunes and a sufficient coastal width (determined by coastal geomorphologicaloceanographic study) represent a necessary condition for limiting the inflow of seawater.

Author Contributions: Conceptualization, N.E.; methodology, N.E., A.P., A.K., and G.S.; investigation, N.E., A.P., A.K., and G.S.; writing-original draft preparation, N.E., A.P., and A.K.; writingreview and editing, N.E., A.P., A.K., and G.S.; visualization, G.S. All authors have read and agreed to the published version of the manuscript.

Funding: This research received no external funding.

Institutional Review Board Statement: Not applicable.

Informed Consent Statement: Not applicable.

Data Availability Statement: Data are contained within the article.

Acknowledgments: Authors would like to thank Manolis Lykouropoulos for his support during field work activities and aerial photography.

Conflicts of Interest: The authors declare no conflict of interest.

\section{References}

1. Nicholls, R.J.; Woodroffe, C.; Burkett, V. Coastline Degradation as an Indicator of Global Change. In Climate Change; Letcher, T.M., Ed.; Elsevier: Amsterdam, The Netherlands, 2016; pp. 309-324. [CrossRef]

2. Orford, J.D.; Pethick, J. Challenging assumptions of future coastal habitat development around the UK. Earth Surf. Process. Landf. 2006, 31, 1625-1642. [CrossRef]

3. Chapin, F.S.; Carpenter, S.R.; Kofinas, G.P.; Folke, C.; Abel, N.; Clark, W.C.; Olsson, P.; Smith, D.M.S.; Walker, B.; Young, O.R.; et al. Ecosystem stewardship: Sustainability strategies for a rapidly changing planet. Trends Ecol. Evol. 2010, 25, 241-249. [CrossRef] [PubMed]

4. Defeo, O.; McLachlan, A.; Schoeman, D.S.; Schlacher, T.A.; Dugan, J.; Jones, A.; Lastra, M.; Scapini, F. Threats to sandy beach ecosystems: A review. Estuar. Coast. Shelf Sci. 2009, 81, 1-12. [CrossRef]

5. UN/MAP Mediterranean Quality Status Report. 2017, p. 539. Available online: https://www.unep.org/unepmap/resources/ quality-status-report-mediterranean-med-qsr-2017 (accessed on 1 November 2021).

6. Brown, A.C.; McLachlan, A. Sandy shore ecosystems and the threats facing them: Some predictions for the year 2025. Environ. Conserv. 2002, 29, 62-77. [CrossRef]

7. Maun, M.A. The Biology of Coastal Sand Dunes; Oxford University Press: Oxford, UK, 2009. [CrossRef]

8. Bertacchi, A. Dune habitats of the Migliarino-San Rossore-Massaciuccoli Regional Park (Tuscany-Italy). J. Maps 2017, 13, 322-331. [CrossRef]

9. Doody, J.P. Coastal squeeze and managed realignment in southeast England, does it tell us anything about the future? Ocean Coast. Manag. 2013, 79, 34-41. [CrossRef]

10. Lithgow, D.; Martínez, M.L.; Gallego-Fernández, J.B. Multicriteria Analysis to Implement Actions Leading to Coastal Dune Restoration. In Restoration of Coastal Dunes; Martínez, M., Gallego-Fernández, J., Hesp, P., Eds.; Springer: Berlin/Heidelberg, Germany, 2013; pp. 307-321.

11. Martinez, M.L.; Gallego-Fernandez, J.B.; Hesp, P.A. (Eds.) Restoration of Coastal Dunes; Springer Series on Environmental Management; Springer: Berlin/Heidelberg, Germany, 2013; ISBN 978-3-642-33444-3.

12. Zalidis, G.C.; Takavakoglou, V.; Gerakis, A. Wetland Rehabilitation in the Mediterranean Basin. In An International Perspective on Wetland Rehabilitation; Streever, W., Ed.; Springer Netherlands: Dordrecht, The Netherlands, 1999; pp. 55-68. [CrossRef]

13. Jansen, J.B.H. Geological map of Greece, island of Naxos, Scale 1:50.000. Inst. Geol. Miner. Resour. 1973.

14. Evelpidou, N.; Melini, D.; Pirazzoli, P.; Vassilopoulos, A. Evidence of a recent rapid subsidence in the S-E Cyclades (Greece): An effect of the 1956 Amorgos earthquake? Cont. Shelf Res. 2012, 39-40, 27-40. [CrossRef]

15. Cordier, S.; Schlüchter, M.-L.; Evelpidou, N.; Pavlopoulos, K.; Bouchet, M.; Frechen, M. Morphology and OSL-based geochronology of the Holocene coastal dunes fields of Naxos Island (Cyclades, Greece): Preliminary results. In Proceedings of the XVIII INQUA Congress, Bern, Switzerland, 20-27 July 2011.

16. Lehmann, A. A three-dimensional baroclinic eddy-resolving model of the Baltic Sea. Tellus A Dyn. Meteorol. Oceanogr. 1995, 47, 1013-1031. [CrossRef]

17. Soukissian, T.; Hatzinaki, M.; Korres, G.; Papadopoulos, A.; Kallos, G.; Anadranistakis, E. Wave and Wind Atlas of the Hellenic Seas, 1st ed.; Hellenic Centre for Marine Research: Athens, Greece, 2007; ISBN 98796086651 9-4. 
18. Karkani, A.; Evelpidou, N.; Vacchi, M.; Morhange, C.; Tsukamoto, S.; Frechen, M.; Maroukian, H. Tracking shoreline evolution in central Cyclades (Greece) using beachrocks. Mar. Geol. 2017, 388, 25-37. [CrossRef]

19. Evelpidou, N.; Pavlopoulos, K.; Vassilopoulos, A.; Triantaphyllou, M.; Vouvalidis, K.; Syrides, G. Holocene palaeogeographical reconstruction of the western part of Naxos island (Greece). Quat. Int. 2012, 266, 81-93. [CrossRef]

20. Evelpidou, N.; Pavlopoulos, K.; Vassilopoulos, A.; Triantaphyllou, M.; Vouvalidis, K.; Syrides, G. Yria (western Naxos island, Greece): Sea level changes in Upper Holocene and palaeogeographical reconstruction. Geodin. Acta 2010, 23, 233-240. [CrossRef]

21. Fouache, E.; Desruelles, S.; Pavlopoulop, K.; Dalongeville, R.; Coquinot, Y.; Peulvast, J.-P.; Potdevin, J.-L. Using beachrocks as sea level indicators in the insular group of Mykonos, Delos and Rhenia (Cyclades, Greece). Z. Fur Geomorphol. 2005, 137, 37-43.

22. Evelpidou, N.; Melini, D.; Pirazzoli, P.A.; Vassilopoulos, A. Evidence of repeated late Holocene rapid subsidence in the SE Cyclades (Greece) deduced from submerged notches. Int. J. Earth Sci. 2013, 103, 381-395. [CrossRef]

23. Saitis, G.; Koutsopoulou, E.; Karkani, A.; Anastasatou, M.; Stamatakis, M.; Gatou, M.-A.; Evelpidou, N. A multi-analytical study of beachrock formation in Naxos and Paros Islands, Aegean Sea, Greece and their palaeoenvironmental significance. Z. Für Geomorphol. 2021, 63, 19-32. [CrossRef]

24. Karkani, A.; Evelpidou, N.; Giaime, M.; Marriner, N.; Morhange, C.; Spada, G. Late Holocene sea-level evolution of Paros Island (Cyclades, Greece). Quat. Int. 2019, 500, 139-146. [CrossRef]

25. Desruelles, S.; Fouache, É.; Ciner, A.; Dalongeville, R.; Pavlopoulos, K.; Kosun, E.; Coquinot, Y.; Potdevin, J.-L. Beachrocks and sea level changes since Middle Holocene: Comparison between the insular group of Mykonos-Delos-Rhenia (Cyclades, Greece) and the southern coast of Turkey. Glob. Planet. Chang. 2009, 66, 19-33. [CrossRef]

26. Sakellariou, D.; Galanidou, N. Pleistocene submerged landscapes and Palaeolithic archaeology in the tectonically active Aegean region. Geol. Soc. Lond. Spec. Publ. 2016, 411, 145-178. [CrossRef]

27. Sakellariou, D.; Tsampouraki-Kraounaki, K. Plio-Quaternary Extension and Strike-Slip Tectonics in the Aegean. In Transform Plate Boundaries and Fracture Zones; Duarte, J., Ed.; Elsevier: Amsterdam, The Netherlands, 2019; pp. 339-374. ISBN 9780128120644.

28. Evelpidou, N. Geomorphological and Environmental Study of Naxos Island Using Remote Sensing and GIS. PhD Thesis, Faculty of Geology and Geoenvironment, National and Kapodistrian University of Athens, Athens, Greece, 2001.

29. IPCC. Climate Change 2007: The Physical Science Basis. Contribution of Working Group I to the Fourth Assessment Report of the Intergovernmental Panel on Climate Change; Solomon, S., Qin, D., Manning, M., Chen, Z., Marquis, M., Averyt, K.B., Tignor, M., Miller, H.L., Eds.; Cambridge University Press: Cambridge, NY, USA, 2007.

30. IPCC. Climate Change 2013-The Physical Science Basis; Intergovernmental Panel on Climate Change, Ed.; Cambridge University Press: Cambridge, NY, USA, 2014; ISBN 9781107415324.

31. Pörtner, H.-O.; Roberts, D.C.; Masson-Delmotte, V.; Zhai, P.; Tignor, M.; Poloczanska, E.; Mintenbeck, K.; Alegría, A.; Nicolai, M.; Okem, A.; et al. (Eds.) IPCC Summary for Policymakers. In IPCC Special Report on the Ocean and Cryosphere in a Changing Climate; 2019.

32. Maroukian, H.; Pavlopoulos, K.; Gaki-Papanastasiou, K.; Zamani, A. The consequences of the expected sea level rise in low lied coastal areas of continental Greece, for the coming century. Geographies 2001, 1, 73-82.

33. Gogou, M.; Macri, E.; Katsetsiadou, K.-N.; Evelpidou, N.; Karkani, E.; Lekkas, E. Tsunami hazard and sand dune protection in west Naxos Isl., Greece. In Proceedings of the SafeCorfu 2019-6th International Conference on Civil Protection \& New Technologies, Corfu, Greece, 6-9 November 2019; pp. 57-60.

34. Al Imran, M.; Kimura, S.; Nakashima, K.; Evelpidou, N.; Kawasaki, S. Feasibility Study of Native Ureolytic Bacteria for Biocementation Towards Coastal Erosion Protection by MICP Method. Appl. Sci. 2019, 9, 4462. [CrossRef] 